\title{
Predictive Factors for Severe Thrombocytopenia and Classification of Causes of Thrombocytopenia in Prema- ture Infants
}

\author{
Hoon Bum Shin, Na Li Yu, Na Mi Lee, Dae Yong Yi, Sin Weon Yun, Soo Ahn Chae, and In Seok Lim \\ Department of Pediatrics, Chung-Ang University College of Medicine, Seoul, Korea
}

\section{ABSTRACT}

Purpose: This study investigated predictive factors for severe neonatal thrombocytopenia, which greatly increases the need for intensive care and is associated with a high mortality rate in premature infants. Factors adopted for prompt identification of at-risk newborns include blood test results and birth history. This study analyzed the relationship between the presence of severe neonatal thrombocytopenia and the mortality rate. The causes of thrombocytopenia in premature infants were also examined. Methods: This retrospective study evaluated 625 premature infants admitted to the neonatal intensive care unit (NICU) at Chung-Ang University Medical Center. The neonates were classified into 3 groups according to the severity of thrombocytopenia: mild $\left(100 \times 10^{9} / \mathrm{L} \leq\right.$ platelet $\left.<150 \times 10^{9} / \mathrm{L}\right)$, moderate $\left(50 \times 10^{9} / \mathrm{L} \leq\right.$ platelet $\left.<100 \times 10^{9} / \mathrm{L}\right)$, or severe (platelet $<50 \times 10^{9} / \mathrm{L}$ ). Analysis of blood samples obtained at the onset of thrombocytopenia included platelet count, white blood cell (WBC) count, hemoglobin level, hematocrit level, absolute neutrophil count, and high-sensitivity C-reactive protein level.

Results: Of the 625 premature infants admitted to our NICU, 214 were detected with thrombocytopenia. The mortality rate in thrombocytopenic neonates was $18.2 \%$ (39/ 214 ), whereas a mortality rate of only $1.0 \%$ was observed in non-thrombocytopenic neonates. The major causes of thrombocytopenia were perinatal insufficiency and sepsis in premature infants. Severe thrombocytopenia was noted more frequently in premature infants with higher WBC counts and in those with a younger gestational age. Conclusion: Platelet count, WBC count, and gestational age are reliable predictors for severe neonatal thrombocytopenia. The major causes of thrombocytopenia were perinatal insufficiency and sepsis in premature infants.

Key Words: Thrombocytopenia, Premature infant, Newborn
Received: 26 July 2017

Revised: 30 October 2017

Accepted: 1 November 2017

Correspondence to: Na Mi Lee

Department of Pediatrics, Chung-

Ang University Hospital, 102,

Heukseok-ro, Dongjak-gu, Seoul

06973, Korea

Tel: +82-2-6299-3181

Fax: +82-2-6264-2167

E-mail:piena81@caumc.or.kr

Copyright(c)

By Korean Society of Neonatology.

All right reserved.

This is an Open-Access article distributed under the terms of the Creative Commons Attribution Non-Commercial License (http://creativecommons.org/licenses/ by-nc/4.0), which permits unrestricted non-commercial use, distribution, and reproduction in any medium, provided the original work is properly cited. 
서론

혈소판 감소증은 신생아에서 가장 흔히 발생하는 혈액학적 이상 질환 중 하나로 신생아의 $1-5 \%$ 에서 발생하며 ${ }^{1-3)}$, 그 중 중증 혈소판 감소증(severe thrombocytopenia)은 신생아의 0.1-0.5\%에서 나타난 다 ${ }^{3-7)}$. 또한 신생아중환자실에 입원하는 환자의 $22-35 \%$ 에서 혈소판 감소증이 발생하며 ${ }^{8,9}$, 이중 약 $20 \%$ 정도에서 중증 혈소판 감소증이 나타나고 특히 미숙아에서 중증 혈소판 감소증의 비율이 높다 ${ }^{10)}$.

신생아중환자실에 입원한 혈소판 감소증 환자의 최대 $50 \%$ 에서 집중 치료가 필요하며 ${ }^{8,11}$, 중증 혈소판 감소증이 동반될 경우 사망 률이 높아진다 ${ }^{12-15)}$. 따라서 중증 혈소판 감소증을 예측할 수 있는 예 측인자(predictive factors)가 있으면 치료 방향을 결정하는데 도움이 될 것이다. 이번 연구에서는 신생아중환자실에 입원한 미숙아에게 시행한 혈액검사와 주산기 정보로부터 중증 혈소판 감소증을 예측 할 수 있는 인자가 있는지 살펴보았으며 혈소판 감소증의 중증도와 재태 기간 출생 체중, 성별, 분만방식, 사망률 등이 통계학적으로 의 미가 있는지 알아봤다. 또한, 혈소판 감소증이 있을 때와 없을 때의 환자 사망률 차이를 분석하였으며 미숙아에서의 혈소판 감소증의 원인을 분류하였다.

\section{대상 및 방법}

\section{1. 대상}

2007년 1월부터 2015년 8월까지 중앙대학교병원 신생아중환자실 에 입원한 미숙아 641 명 중 전원간 16 명을 제외한 625 명의 의무 기록 과 피검사 결과를 후향적(retrospective)으로 분석하였으며 이 중 혈 소판 감소증이 있었던 환자 214 명을 중심으로 연구를 진행하였다.

\section{2. 혈소판 감소증, 조기발생 혈소판 감소증(early-onset thrombocytopenia), 미숙아, 초미숙아(extreme prema- turity)의 정의}

현재까지 많은 연구에서 태아의 정상 혈소판 수치는 임신 2 분기 때 $150 \times 10^{9} / \mathrm{L}$ 이상이며 ${ }^{1,16)}$ 그 후 출생 시까지 그 수치를 지속적으로 유지하는 것으로 알려졌다 ${ }^{5,16)}$. 따라서 건강하게 태어난 신생아에서 의 정상 혈소판 수치는 $150 \times 10 \% / \mathrm{L}$ 이상으로 보고 혈소판 감소증은 혈소판 수치가 $150 \times 10^{9} / \mathrm{L}$ 미만일 경우로 간주하였다 ${ }^{16,17)}$. 실험실적 오류를 배제하기 위해 입원 중 두 번 연속 혈소판 수치가 $150 \times 10^{9} / \mathrm{L}$ 미만일 경우만 혈소판 감소증이 있는 환자로 생각하고 처음 혈소판 수치가 $150 \times 10 \% / \mathrm{L}$ 미만인 날을 혈소판 감소증이 발생한 날로 판단하 였다. 조기발생 혈소판 감소증은 생후 72 시간 이전에 발생한 혈소판 감소증 ${ }^{18}$, 미숙아는 다양한 문헌을 참고하여 재태 기간 37 주 미만, 초미숙아는 재태 기간 28 주 미만으로 정의 하였다 ${ }^{19)}$.

\section{3. 혈액검사와 혈소판 수혈 지침}

본원에서 태어난 후 신생아중환자실에 입원한 환자는 첫 3일간 매 일 전혈구계산(complete blood count)을 포함한 혈액검사를 시행하 게 되며 타 병원에서 전원 온 경우 출생 3 일까지는 매일, 출생 3 일 이 후에 전원 온 경우는 입원일 혈액검사를 시행했다. 또한 혈액검사에 서 혈소판 수치가 $50 \times 10 \% / \mathrm{L}$ 미만 이거나 채혈 과정에서 미숙한 술기 로 혈소판 수치가 낮게 나온 것이 의심되면 바로 재검사를 시행하며 혈소판 수치가 $150 \times 10^{9} / \mathrm{L}$ 미만일 경우는 익일 재채혈을 시행하였다.

본원에서 혈소판 감소증 환자의 혈소판 수혈은 신중히 이루어졌 다. 혈소판 수치가 $50 \times 10^{9} / \mathrm{L}$ 이상일 경우 큰 출혈의 증거가 없으면 혈소판 수혈은 하지 않으며 $30 \times 10^{9} / \mathrm{L}$ 이상, $50 \times 10^{9} / \mathrm{L}$ 미만일 경우 출 생 체중이 $1,000 \mathrm{~g}$ 이하, 패혈증 의심, 이전에 출혈이 있었던 경우 신 중히 수혈을 진행하고 $30 \times 10 \%$ /L미만인 경우는 모든 환자에게 수혈 을 시행하였다. 신생아 idiopathic thrombocytopenic purpura (ITP) 가 의심되는 경우 intravenous immunoglobulin (IVIG)와 함께 스테 로이드를 치료에 사용하였다. 중증 혈소판 감소증 환자의 경우 수혈 후 잠시 혈소판 수치가 $150 \times 10^{9} / \mathrm{L}$ 이상으로 회복되었다 하더라도 바 로 악화되는 경우가 많기 때문에 이럴 경우 혈소판 감소증이 호전되 었다 보지 않고 필요에 따라 하루에 한번 이상 혈액검사를 시행하여 수치가 낮으면 추가수혈을 진행하였다.

\section{4. 분석 정보}

혈소판 감소증이 나타났던 미숙아들의 주산기력, 혈액검사 결 과에 대한 연구를 진행하였다. 재태 기간, 출생 체중, 출생 방식, 성 별, 사망 여부, 출생 후 혈소판 감소증이 발생한 시간, 혈소판 감소증 으로부터 회복 여부 및 회복 기간을 알아봤다. 혈액검사 결과로는 혈소판, 백혈구, 혈색소, 적혈구 용적률, absolute neutrophil count (ANC), high-sensitivity C-reactive protein (Hs-CRP), aspartate trans aminase (AST), alanine transaminase (ALT)을 함께 분석 했다. 또한 초미숙아를 제외한 미숙아와 초미숙아 두 집단에서 혈소판 감소증 의 원인에 대해서 조사하였다. 패혈증이 원인인 경우는 고체온 및 저체온, 빠른 맥, 빠른 호흡, 백혈구 증가 또는 감소 같은 전신 염증 반응 증후군의 증거와 혈액 배양검사에서 원인균이 증명 또는 강력 히 의심되는 경우로 한정하였다.

\section{5. 주요 결과 측정}

크게 네 가지 관점에서 연구를 진행하였다. 첫 번째로 신생아중환 자실에 입원한 미숙아 중 혈소판 감소증이 발생한 신생아와 그렇지 않은 신생아의 사망률 비교하였다. 두 번째로 혈소판 감소증이 발생 한 신생아를 중증도에 따라 경증 $\left(100 \times 10^{9} / \mathrm{L} \leq\right.$ platelet $\left.<150 \times 10^{9} / \mathrm{L}\right)$, 중등도 $\left(50 \times 10^{9} / \mathrm{L} \leq\right.$ platelet $\left.<100 \times 10^{9} / \mathrm{L}\right)$, 중증 (platelet $\left.<50 \times 10^{9} / \mathrm{L}\right)$, 세 군으로 나누고 ${ }^{9}$ 세 군 간의 출생 체중, 재태 기간, 성별, 분만방식 등 
의 출생정보와 조기 발생 혈소판 감소증 비율, 혈소판 감소증으로 부터 회복되는 비율, 혈소판 감소증 진행 기간, 출생 후 혈소판 감소 증 발병까지 걸린 시간 그리고 사망률 등을 비교했다. 세 번째로 신 생아에서의 중증 혈소판 감소증을 예측할 수 있는 인자가 무엇이 있 을지 논의 해 봤으며 이를 위해 경증, 중등도 혈소판 감소증 군을 합 치고 중증 혈소판 감소증 군과 비교하였다. 비교 정보는 처음 혈소 판 감소증이 진단되었을 때 함께 시행했던 혈소판, 백혈구, 혈색소, 적혈구 용적률, absolute neutrophil count (ANC), high-sensitivity C-reactive protein (Hs-CRP), aspartate transaminase (AST), alanine transaminase (ALT) 등의 혈액검사 수치와 재태 기간, 출생 체중이었 다. 마지막으로 혈소판 감소증이 발생한 미숙아를 초미숙아 군과 초 미숙아를 제외한 미숙아 군으로 나누어 혈소판 감소증을 일으킨 원 인 질환에 따라 분류해 보았으며 각 군의 재태 기간, 출생 체중, 혈소 판 감소증이 처음 발생 했을 때 혈소판 수치, 출생 후 혈소판 감소증 발병까지 걸린 시간을 분석하였다.

\section{6. 통계분석}

이번 연구에서는 IBM SPSS Statistics version 19 (IBM Co., Armonk, $\mathrm{NY}, \mathrm{USA}$ )를 사용하여 통계분석을 시행하였다. 세 군 간의 비교를 위 해 연속변수는 평균士표준편차로 나타내었으며 일원배치 분산분석 (oneway ANOVA)을 사용하였다. 명목형 변수는 $\chi^{2}$ 검정(Pearson's Chi-square test)을 사용하여 분석하였고 단변량 분석에서 유의미한 차이를 보였던 변수를 포함하여 이분형 로지스틱 회귀 분석(binary logistic regression analysis)을 사용하였다. 본 연구는 중앙대학교병 원 기관생명윤리 위원회의 승인을 받았다.

\section{결과}

\section{1. 혈소판 감소증이 있었던 미숙아와 없었던 미숙아 간의 사 망률 비교}

대상 기간 동안 641 명의 미숙아가 신생아중환자실에 입원했으며
16 명은 치료 중 타병원으로 전원을 갔다. 남은 625명 중 6.9\%에 해 당하는 43명이 본원에서 사망하였다(Figure 1). 625명 중 혈소판 감 소증이 있다고 진단된 환자는 214 명이었으며 혈소판 감소증이 없었 던 환자는 411 명이었다. 이 411명 중에서 사망한 신생아는 4 명으로 사망률은 $1.0 \%$ 였다. 혈소판 감소증이 있었던 214 명 중 39 명이 사망 하여 사망률은 $18.2 \%$ 였다. 혈소판 감소증이 있었던 환자 군에서의 사망률은 그렇지 않았던 군보다 약 18 배 높았다. 혈소판 감소증이 있었던 환자군에서 사망한 39 명 중 24 명은 혈소판 감소증에서 회복 하지 못한 채 사망하였으며 직접 사인은 패혈증이 9명으로 가장 많 았고 파종성 혈관내 응고증 6명, 심부전, 신생아 폐동맥 고혈압 지속 증 각각 4 명, 신부전 3 명 순이었다.

\section{2. 혈소판 감소증의 정도에 따른 세 군 간의 정보 비교}

혈소판 감소증의 정도에 따라 214 명의 환자를 경증, 중등도, 중증 의 세 군으로 나누었다(Table 1). 주산기 정보를 비교 본 결과 혈소 판 감소증의 중증도가 증가할수록 재태 기간은 경증 혈소판 감소증 군에서 중증 혈소판 감소증 군으로 갈수록 평균 값이 짧아지는 경향 이 있었으며 세 군 간의 유의 확률 또한 통계적으로 의미 있는 결과 가 나왔다. 반면 출생 체중, 출산 방식, 성별은 세 군간에 통계적으로 유의한 결과를 도출하지 못하였다. 혈소판 감소증으로부터 회복되 는 기간은 중증도가 증가할수록 평균값이 증가하였지만 세 군을 모 두 비교했을 때 통계적으로 유의한 결과를 도출하지 못하였다. 출생 후 혈소판 감소증 발병까지 걸린 시간은 경증 혈소판 감소증에서 출

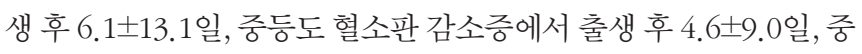
증 혈소판 감소증에서 출생 후 $6.6 \pm 10.9$ 일에 발생하였으며 세 군 모 두에서 혈소판 감소증의 중증도와 통계학적 연관이 없었다. 조기발 생 혈소판 감소증 비율은 혈소판 감소증의 중증도와 상관이 없었지 만 혈소판 감소증으로부터 회복되는 비율은 혈소판 감소증의 중증 도가 증가할수록 수치가 통계적으로 유의하게 감소하는 것을 확인 할 수 있으며 사망률은 중증도가 증가할 수록 통계적으로 유의하게 증가하였다. 중증 혈소판 감소증 환자 66 명 중 혈소판 수혈을 받은 환자는 총 48 명이었으며 혈소판 수혈을 시행한 횟수는 평균 $4.2 \pm 2.7$

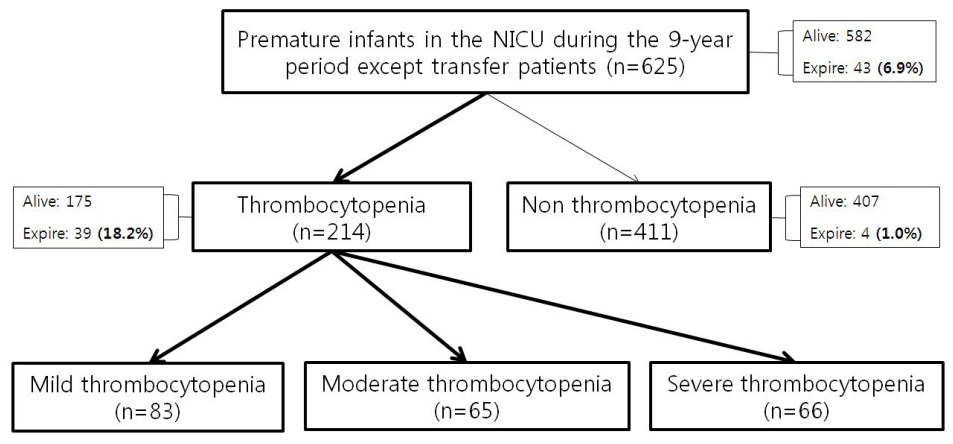

Figure 1. Study flow diagram to identify premature infants in neonatal intensive care unit. Abbreviation: NICU, neonatal intensive care unit. 
Table 1. Comparison of Patient's Birth History and Characteristics of Thrombocytopenia Between Three Groups

\begin{tabular}{|c|c|c|c|c|}
\hline & $\begin{array}{l}\text { Mild thrombocytopenia } \\
\qquad(\mathrm{n}=\mathbf{8 3})\end{array}$ & $\begin{array}{l}\text { Moderate thrombocytopenia } \\
\qquad(\mathrm{n}=65)\end{array}$ & $\begin{array}{l}\text { Severe thrombocytopenia } \\
\qquad(\mathrm{n}=66)\end{array}$ & $P$-value \\
\hline Gestational age (wks) & $32.3 \pm 2.9$ & $30.8 \pm 3.7$ & $28.8 \pm 3.8$ & 0.014 \\
\hline Birth weight (g) & $1,961.7 \pm 2,304.6$ & $1,400.8 \pm 588.1$ & $1,263.7 \pm 587.3$ & 0.604 \\
\hline Cesarean delivery & $61(73.5)$ & $46(70.8)$ & $48(72.7)$ & 0.933 \\
\hline Male & $52(62.7)$ & $33(50.8)$ & $40(60.6)$ & 0.315 \\
\hline Outbreak of thrombocytopenia after birth (d) & $6.1 \pm 13.1$ & $4.6 \pm 9.0$ & $6.6 \pm 10.9$ & 0.817 \\
\hline Recovery duration from thrombocytopenia (d) & $3.5 \pm 3.1$ & $8.0 \pm 13.0$ & $9.0 \pm 16.1$ & 0.137 \\
\hline Early onset & $54(65.1)$ & $45(69.2)$ & $41(62.1)$ & 0.691 \\
\hline Recovery from thrombocytopenia & $79(95.2)$ & $57(87.7)$ & $39(59.1)$ & $<0.001$ \\
\hline Expire & $3(3.6)$ & $9(13.8)$ & $27(40.9)$ & $<0.001$ \\
\hline
\end{tabular}

Data are expressed as mean \pm SD or $\mathrm{n}(\%)$.

$P$-value was statistically significant at $<0.05$.

Table 2. Risk Factors to Severe Thrombocytopenia

\begin{tabular}{|c|c|c|c|c|c|}
\hline & $\begin{array}{l}\text { Mild + moderate thrombocytopenia } \\
\qquad(\mathrm{n}=148)\end{array}$ & $\begin{array}{l}\text { Severe thrombocytopenia } \\
\qquad(\mathrm{n}=66)\end{array}$ & Odds Ratio & $\begin{array}{l}\text { 95\% Confidence } \\
\text { Interval }\end{array}$ & $P$-value \\
\hline Platelet $\left(10^{9} / \mathrm{L}\right)$ & $124.8 \pm 22.9$ & $104.7 \pm 38.9$ & 0.975 & $0.963-0.987$ & $<0.001$ \\
\hline $\operatorname{WBC}\left(10^{9} / \mathrm{L}\right)$ & $10.6 \pm 6.7$ & $13.8 \pm 12.7$ & 1.072 & $1.011-1.141$ & 0.021 \\
\hline $\operatorname{ANC}(\mu \mathrm{L})$ & $7,216.6 \pm 7,522.8$ & $6,868.3 \pm 7,781.5$ & 1.000 & $1.000-1.000$ & 0.113 \\
\hline Hs-CRP (mg/L) & $8.3 \pm 29.4$ & $17.4 \pm 34.0$ & 1.002 & 0.993-1.012 & 0.634 \\
\hline Hemoglobin (g/dl) & $14.7 \pm 3.5$ & $12.8 \pm 3.4$ & 0.887 & $0.598-1.316$ & 0.551 \\
\hline Hematocrit (\%) & $43.8 \pm 9.8$ & $38.2 \pm 9.8$ & 0.979 & $0.854-1.123$ & 0.763 \\
\hline AST (IU/L) & $60.33 \pm 69.2$ & $84.7 \pm 118.6$ & 0.999 & 0.993-1.005 & 0.742 \\
\hline $\operatorname{ALT}(\mathrm{IU} / \mathrm{L})$ & $12.2 \pm 19.7$ & $24.3 \pm 44.5$ & 1.009 & $0.992-1.026$ & 0.322 \\
\hline Gestational age (wks) & $31.6 \pm 3.3$ & $29.3 \pm 3.8$ & 0.854 & $0.751-0.970$ & 0.015 \\
\hline Birth weight (g) & $1,715.3 \pm 1,786.4$ & $1,263.7 \pm 587.3$ & 1.000 & 0.999-1.001 & 0.619 \\
\hline
\end{tabular}

Data are expressed as mean $\pm \mathrm{SD}$.

$P$-value was statistically significant at $<0.05$.

Abbreviations: ANC, absolute neutrophil count; Hs-CRP, high-sensitivity C-reactive protein; AST, aspartate transaminase; ALT, alanine transaminase.

회였다. 또한 66 명 중 27 명이 퇴원 시까지 혈소판 수치가 회복되지 않았으며 이 중 사망자는 24 명이었고 3 명은 혈소판 수치가 $100 \times 10^{9}$ \% $\mathrm{L}$ 이상인 상태에서 퇴원하였다.

총 214 명의 환자 중 본원에서 태어난 환자는 191 명이었고 환자 어머니의 혈소판 감소증 동반 여부도 함께 연구해 본 결과 경증 혈 소판 감소증 환자 83 명 중 57 명이 본원에서 태어났으며 그 중 17 명 (29.8\%)의 환자 어머니가 입원 시 혈소판 감소증이 있었다. 중등도 혈소판 감소증 환자 총 65 명 중 47 명이 본원에서 출생했으며 13 명 (27.7\%)의 환자 어머니에서 혈소판 감소증이 발견되었고 중증 혈소 판 감소증 환자 66 명 중 본원에서 태어난 40 명을 분석한 결과 17 명 $(42.5 \%)$ 의 환자 어머니가 혈소판 감소증이 있었다. 결과적으로 중 증 혈소판 감소증 환자의 어머니에서 혈소판 감소증이 가장 많이 나 타나기는 하였지만 세 군 간의 통계적 유의성은 없었다. 파종성 혈관
내 응고가 발생한 어머니는 191명 중 한 명이었으며 아기는 중증 혈 소판 감소증 환자였고 패혈증으로 사망하였다. 태반 조직 검사는 총 191 명 중 22 명에게 시행되었으며 이 중 2 명에게서 융모양막염이 발 견되었다. 융모양막염이 발견된 어머니의 아기에 대해 살펴보면 한 명은 중증 혈소판 감소증 환자로 파종성 혈관내 응고로 사망하였고 다른 한 명은 경증 혈소판 감소증 환자로 사망하지 않고 퇴원하였다.

\section{3. 중증 혈소판 감소증의 예측인자}

연구를 위해 경증과 중등도 군을 합친 후 중증 혈소판 감소증 군 과 비교하였다. 경증과 중등도 군은 총 148 명이었고 중증 혈소판 감 소증 군은 총 66명 이었다(Table 2). 비교를 시행한 혈액검사 결과는 혈소판 감소증이 처음 발생했을 때 함께 시행했던 혈소판, 백혈구, 혈색소, 적혈구 용적률, $\mathrm{ANC}, \mathrm{Hs}-\mathrm{CRP}, \mathrm{AST}, \mathrm{ALT}$ 수치였다. 결과적 
으로 혈소판, 백혈구 수치에서 두 그룹 간에 의미 있는 차이가 있었 다. 혈액검사 결과값과 함께 출생 정보인 재태 기간, 출생 체중도 함 께 분석하였으며 재태 기간이 짧을수록 중증 혈소판 감소증에 빠질 수 있는 가능성이 높다는 것을 알 수 있었다.

\section{4. 초미숙아 군과 초미숙아가 아닌 군 간의 혈소판 감소증의 원인 분류와 정보 비교}

214 명의 미숙아를 초미숙아 군과 초미숙아가 아닌 군으로 나누 어 연구를 진행하였다. 재태 기간은 초미숙아 군 $26.0 \pm 1.4$ 주 초미 숙아가 아닌 군에서 $32.5 \pm 2.5$ 주 인 것으로 나타났으며 출생 체중 은 각각 879.6 $\pm 268.0 \mathrm{~g}, 1,805.3 \pm 1,700.9 \mathrm{~g}$ 이었다(Table 3). 초미숙

Table 3. Comparison of Patient Information between Extremely Premature Infants and Premature Infants except Extremely Premature Infants

\begin{tabular}{lccr}
\hline & $\begin{array}{c}\text { Premature infants } \\
\text { except extremely } \\
\text { premature infants } \\
(\mathrm{n}=161)\end{array}$ & $\begin{array}{c}\text { Extremely } \\
\text { premature } \\
\text { infants } \\
(\mathrm{n}=53)\end{array}$ & P-value \\
& $32.5 \pm 2.5$ & $26.0 \pm 1.4$ & $<0.001$ \\
\hline Gestational age (wks) & $1,805.3 \pm 1,700.9$ & $879.6 \pm 268.0$ & $<0.001$ \\
Birth weight (g) & $119.1 \pm 31.4$ & $116.9 \pm 26.2$ & 0.614 \\
Platelet $\left(10^{9} / \mathrm{L}\right)$ & $5.3 \pm 11.6$ & $7.3 \pm 10.8$ & 0.250 \\
$\begin{array}{l}\text { Outbreak of thrombo- } \\
\text { cytopenia after birth }(\mathrm{d})\end{array}$ & & & \\
\hline
\end{tabular}

Data are expressed as mean \pm SD.

$P$-value was statistically significant at $<0.05$.
아 군에서는 원인 불명의 경우를 제외하고 패혈증이 53 명 중 13 명 으로 그 비율이 가장 높았으며 괴사성 장염이 6명으로 그 뒤를 이었 다(Table 4). 초미숙아가 아닌 군에서는 산모의 주산기 문제로 인하 여 태아에게 부정적인 영향을 줄 수 있는 질환인 전자간증, 임신성 고혈압, 자궁내 성장 지연 등을 포함하는 출생전후기 부전(perinatal insufficiency) $)^{20)}$ 이 161 명 중 39 명을 차지 하였다. 그 다음으로 패혈 증이 24 명으로 비율이 높았다. 두 군을 합쳐 검토해 보면 출생전후 기 부전 43 건 중 자궁내 성장 장애가 18 건, 전자간증 17 건으로 높은 비율을 차지 하였으며 임신성 고혈압이 4건으로 나타났다.

\section{고찰}

9년간 신생아중환자실에 입원했던 미숙아 중 혈소판 감소증이 있 었던 환자의 사망률은 $18.2 \%$ 인 반면 혈소판 감소증이 없었던 환자 들의 사망률은 $1.0 \%$ 였다. 혈소판 감소증은 다른 질환과 함께 발생하 는 경우가 많으며 따라서 혈소판 감소증 있는 신생아들은 다른 동반 질환을 가질 가능성이 높고 이에 따라 사망률이 높아진 것으로 생각 해 볼 수 있다. 결론적으로 혈소판 감소증 때문에 사망률이 $18.2 \%$ 가 되었다고 직접 연결시키는 것은 무리가 있어 보인다. 하지만 환자가 가지고 있던 다른 질환에 대한 영향을 배제하지 못하더라도 혈소판 감소증이 있었던 군에서 그렇지 않았던 군보다 사망률이 약 18 배나 높게 나온 것은 충분히 의미 있는 수치라고 할 수 있다. 이에 따라 미 숙아에서 혈소판 감소증이 있을 경우 좀 더 주의를 기울여 환자를 관

Table 4. Causes of Thrombocytopenia

\begin{tabular}{|c|c|c|c|}
\hline & Condition & $\begin{array}{l}\text { Premature infants except } \\
\text { extremely premature infants } \\
\qquad(n=161)\end{array}$ & $\begin{array}{l}\text { Extremely premature infants } \\
\qquad(\mathrm{n}=53)\end{array}$ \\
\hline \multirow[t]{2}{*}{ Fatal } & Congenital infection (e.g. CMV, syphilis) & $3(1.9)$ & $0(0.0)$ \\
\hline & Aneuploidy (e.g. trisomies 18, 13, 21 or triploidy) & $5(3.1)$ & $1(1.9)$ \\
\hline \multirow{7}{*}{$\begin{array}{l}\text { Early onset neonatal } \\
\qquad(<72 \text { hours })\end{array}$} & Perinatal insufficiency (e.g. PET, IUGR, PIH, diabetes) & $39(24.2)$ & $4(7.5)$ \\
\hline & Sepsis & $4(2.5)$ & $4(7.5)$ \\
\hline & Perinatal asphyxia & $2(1.2)$ & $1(1.9)$ \\
\hline & Perinatal infection (e.g. Candida albicans, GBS) & $1(0.6)$ & $0(0.0)$ \\
\hline & DIC & $8(5.0)$ & $1(1.9)$ \\
\hline & Autoimmune (e.g. ITP, SLE) & $1(0.6)$ & $0(0.0)$ \\
\hline & Metabolic disease (e.g. methylmalonic academia) & $1(0.6)$ & $0(0.0)$ \\
\hline \multirow{3}{*}{$\begin{array}{l}\text { Late onset neonatal } \\
\text { ( } \geq 72 \text { hours) }\end{array}$} & Sepsis & $20(12.4)$ & $9(17.0)$ \\
\hline & NEC & $10(6.2)$ & $6(11.3)$ \\
\hline & DIC & $88(5.0)$ & $0(0.0)$ \\
\hline Idiopathic & & $59(36.6)$ & $27(45.7)$ \\
\hline
\end{tabular}

Data are expressed as $\mathrm{n}(\%)$.

Abbreviations: CMV, cytomegalovirus; PET, pre-eclampsia; IUGR, intra-uterine growth retardation; PIH, pregnancy induced hypertension; GBS, group B streptococcus; DIC, disseminated intravascular coagulation; ITP, idiopathic thrombocytopenic purpura; SLE, systemic lupus erytematosus; NEC, necrotizing enterocolitis. 
찰 할 필요가 있다고 생각된다.

혈소판 감소증을 경증, 중등도, 중증 세 군으로 나누어 혈소판 감 소증의 중증도와 혈소판 감소증으로부터 회복되는 시간, 출생 후 혈 소판 감소증 발병까지 걸린 시간, 조기 발생 혈소판 감소증 비율, 혈 소판 감소증으로부터 회복 비율, 사망률에 유의미한 차이가 있는지 알아봤다. 결과적으로 중증도가 높아질수록 혈소판 감소증으로부 터 회복되는 비율은 낮았고 사망하는 비율은 높았다. 중증 혈소판 감소증에서 사망률이 높다는 것은 이미 알려진 사실이며 ${ }^{1421-23)}$, 이에 따라서 혈소판 감소증으로부터 회복되는 비율이 낮아진다는 것은 예측해 볼 수 있는 결과라 생각 된다 ${ }^{14,211}$.

중증 혈소판 감소증이 발생한 미숙아는 사망률이 매우 높은 것 으로 알려져 있다. 따라서 중증 혈소판 감소증을 예측할 수 있는 인 자들이 있다면 치료 계획 수립에 도움이 될 수 있을 것이다. 현재 까지 여러 연구를 통해 중증 혈소판 감소증의 위험 요소가 밝혀졌 다. 산모 측 요인을 보면 Tirupathi 등 ${ }^{24)}$ 은 임신성 고혈압, 조기 양막 파수, 양수 과소증 등이 있을 경우 출생아가 중증 혈소판 감소증에 빠질 가능성이 높다는 연구 결과를 발표했다. 아기 측 요인으로는 Kamphuis 등 ${ }^{25)}$ 의 연구에서 신생아 동종면역 혈소판 감소증이 있을 경우 뇌출혈과 함께 중증 혈소판 감소증이 나타날 위험성이 높아진 다고 주장하였으며 Tighe 등 ${ }^{26}$ 의 연구에서는 선천적으로 사람 면역 결핍 바이러스에 감염 되었을 경우 중증 혈소판 감소증의 가능성이 높아 질 수 있다고 말하였다. 또한 Beiner 등 ${ }^{27}$ 의 연구에서는 부당 경 량아를 중증 혈소판 감소증의 위험 요소로 꼽았다. 비록 다양한 연 구를 통해 중증 혈소판 감소증의 위험 요소가 많이 밝혀졌지만 혈액 검사 결과로부터 중증 혈소판 감소증의 위험성을 예측할 수 있는 연 구는 거의 이루어지지 않았다. 본 연구에서는 혈소판 감소증이 처음 발생했을 때 함께 시행한 혈액검사 결과를 중증 혈소판 감소증의 예 측인자로 사용할 수 있는지 검토하였다. 처음 혈소판 감소증이 발생 했을 때 시행한 혈액검사 수치를 비교해 본 결과 혈소판 수치가 낮을 수록, 그리고 백혈구 수치가 높을수록 중증 혈소판 감소증으로 이행 될 가능성이 높았다. 또한, 재태 기간이 짧을수록 중증 혈소판 감소 증이 발생할 가능성이 높은 반면 출생 체중과는 관련이 적은 것으로 나타났다. 이는 같은 군이라고 하더라도 출생 체중은 환자에 따라 차이가 큰 반면에 재태 기간은 그 차이가 크지 않고 비교적 균일하였 기 때문으로 판단된다.

혈소판 감소증의 원인 중 패혈증이 총 37 명에서 발견 되었다. 초 미숙아를 제외한 미숙아군 161명 중 패혈중은 24명으로 출생전후 기 부전 다음 순위를 차지하였지만 초미숙아군에서는 53명 중 13 명에서 패혈증이 혈소판 감소증의 원인으로 작용하여 가장 많은 수 를 차지하였다. 패혈증이 원인인 총 37 명 중 혈액 배양검사 결과 균 이 증명된 경우는 27 명 이었다. 27 명 중 16 명이 초미숙아을 제외한 미숙아군에서 균이 동정되었으며 대부분이 그람 양성균이었고 그 람 음성균과 곰팡이는 4 건이었다. 초미숙아군에서는 11 명에서 균
이 동정되었고 이 중 5건이 그람 음성균(Klebsiella pneumonia 2건, Enterobacter cloacae 1건)이나 곰팡이(Candida albicans 2건)로 거 의 절반을 차지하였다. 이러한 결과는 Ohlin 등 ${ }^{28)}$ 의 초미숙아 패혈 증에 대한 연구에서 동정된 균 324 건 중 78 건이 그람 음성균이나 곰 팡이였 던 것과 비교하면 높은 수치이다. Guida 등 ${ }^{29)}$ 이 출생체중 $1,500 \mathrm{~g}$ 미만의 극소 저체중 출생아(very low birth weight)를 대상으 로 시행한 연구를 보면 그람 양성균 패혈증과 비교하여 그람 음성균 이나 곰팡이에 의한 패혈증에서 혈소판 감소증을 일으키는 경우가 더 많았고 혈소판 감소증으로부터 회복되는 시간도 더 오래 걸렸다. 초미숙아군 53명 모두 극소 저체중 출생아에 속하였고 또한 패혈증 의 원인으로 그람 음성균이나 곰팡이 비율이 상당히 높은 상황을 검 토해 보면 그람 음성균이나 곰팡이에 의한 패혈증이 혈소판 감소증 을 많이 일으키고, 이는 초미숙아군 혈소판 감소증의 원인 중 패혈증 이 가장 높은 비율을 차지하는데 영향을 미쳤을 것으로 보인다.

본 연구는 몇 가지 제한점을 가지고 있다. 이번 연구에서는 입원 후 다른 병원으로 전원간 환자들은 추적하지 않았으며 이러한 환자 들은 통계에서 배제하였다. 전원간 환자들은 보통 여러 질환을 가지 고 있으며 나쁜 예후를 보이는 경우가 많았다. 이러한 환자들을 배 제하고 연구를 진행하였기 때문에 연구 자료에 치우침(bias)이 있을 수 있다. 이번 연구에서는 단순히 신생아중환자실에 입원한 미숙아 중 혈소판 감소증이 있었던 환자와 없었던 환자의 사망률을 비교하 였다. 다른 조건 통제하에 혈소판 감소증의 유무에서만 차이가 있는 환자 군을 대상으로 사망률은 비교하면 혈소판 감소증이 사망에 미 치는 영향을 좀 더 정확히 분석해 볼 수 있을 것이다. 또한 혈소판 감 소증의 중증도에 따라 세 군으로 나누면서 재태기간 별 보정 또는 혈 소판 감소증 발생 시기별 보정 등이 이루어 지지 않았다. 이런 보정 이 이루어진다면 좀 더 명확한 값은 도출 해 낼 수 있을 것이다.

\section{REFERENCES}

1) Pahal GS, Jauniaux E, Kinnon C, Thrasher AJ, Rodeck CH. Normal development of human fetal hematopoiesis between eight and seventeen weeks' gestation. Am J Obstet Gynecol 2000;183:1029-34.

2) Burrows RF, Kelton JG. Incidentally detected thrombocytopenia in healthy mothers and their infants. N Engl J Med 1988;319:1425.

3) Sainio S, Jarvenpaa AL, Renlund M, Riikonen S, Teramo K, Kekomaki R. Thrombocytopenia in term infants: a populationbased study. Obstet Gynecol 2000;95:441-6.

4) de Moerloose P, Boehlen F, Extermann P, Hohfeld P. Neonatal thrombocytopenia: incidence and characterization of maternal antiplatelet antibodies by MAIPA assay. Br J Haematol 1998; 100:735-40. 
5) Burrows RF, Kelton JG. Fetal thrombocytopenia and its relation to maternal thrombocytopenia. N Engl J Med 1993;329:1463-6.

6) Uhrynowska M, Niznikowska-Marks M, Zupanska B. Neonatal and maternal thrombocytopenia: incidence and immune background. Eur J Haematol 2000;64:42-6.

7) Dreyfus M, Kaplan C, Verdy E, Schlegel N, Durand-Zaleski I, Tchernia G. Frequency of immune thrombocytopenia in newborns: a prospective study. Blood 1997;89:4402-6.

8) Murray NA, Roberts IA. Circulating megakaryocytes and their progenitors in early thrombocytopenia in preterm neonates. Pediatr Res 1996;40:112-9.

9) Sola-Visner M, Sallmon H, Brown R. New insights into the mechanisms of nonimmune thrombocytopenia in neonates. Semin Perinatol 2009;33:43-51.

10) Murray NA, Howarth LJ, McCloy MP, Letsky EA, Roberts IA. Platelet transfusion in the management of severe thrombocytopenia in neonatal intensive care unit patients. Transfus Med 2002;12:35-41.

11) Roberts I, Stanworth S, Murray NA. Thrombocytopenia in the neonate. Blood Rev 2008;22:173-86.

12) Christensen RD, Baer VL, Henry E, Snow GL, Butler A, SolaVisner MC. Thrombocytopenia in small-for-gestational-age infants. Pediatrics 2015;136:e361-70.

13) Carr R, Kelly AM, Williamson LM. Neonatal thrombocytopenia and platelet transfusion - a UK perspective. Neonatology 2015; 107:1-7.

14) Muthukumar P, Venkatesh V, Curley A, Kahan BC, Choo L, Ballard S, et al. Severe thrombocytopenia and patterns of bleeding in neonates: results from a prospective observational study and implications for use of platelet transfusions. Transfus Med 2012;22:338-43.

15) Arnold DM. Positioning new treatments in the management of immune thrombocytopenia. Pediatr Blood Cancer 2013;60 Suppl 1:S19-22.

16) Wiedmeier SE, Henry E, Sola-Visner MC, Christensen RD. Platelet reference ranges for neonates, defined using data from over 47,000 patients in a multihospital healthcare system. J Perinatol 2009;29:130-6.

17) Saxonhouse MA, Sola MC, Pastos KM, Ignatz ME, Hutson AD, Christensen $\mathrm{RD}$, et al. Reticulated platelet percentages in term and preterm neonates. J Pediatr Hematol Oncol 2004;26:797-
802.

18) Fustolo-Gunnink SF, Vlug RD, Smits-Wintjens VE, Heckman EJ, Te Pas AB, Fijnvandraat K, et al. Early onset thrombocytopenia in small for gestational age neonates: a retrospective cohort study. PLoS One 2016;11:e0154853.

19) Glass HC, Costarino AT, Stayer SA, Brett CM, Cladis F, Davis PJ. Outcomes for extremely premature infants. Anesth Analg 2015;120:1337-51.

20) Roberts I, Murray NA. Neonatal thrombocytopenia: causes and management. Arch Dis Child Fetal Neonatal Ed 2003;88:F35964.

21) Stanworth SJ, Clarke P, Watts T, Ballard S, Choo L, Morris T, et al. Prospective, observational study of outcomes in neonates with severe thrombocytopenia. Pediatrics 2009;124:e826-34.

22) Valat AS, Caulier MT, Devos P, Rugeri L, Wibaut B, Vaast $P$, et al. Relationships between severe neonatal thrombocytopenia and maternal characteristics in pregnancies associated with autoimmune thrombocytopenia. Br J Haematol 1998;103:397401.

23) Baer VL, Lambert DK, Henry E, Christensen RD. Severe thrombocytopenia in the NICU. Pediatrics 2009;124:e1095-100.

24) Tirupathi K, Swarnkar K, Vagha J. Study of risk factors of neonatal thrombocytopenia. International Journal of Contemporary Pediatrics 2016;4:191.

25) Kamphuis MM, Paridaans NP, Porcelijn L, Lopriore E, Oepkes D. Incidence and consequences of neonatal alloimmune thrombocytopenia: a systematic review. Pediatrics 2014;133: 715-21.

26) Tighe P, Rimsza LM, Christensen RD, Lew J, Sola MC. Severe thrombocytopenia in a neonate with congenital HIV infection. J Pediatr 2005;146:408-13.

27) Beiner ME, Simchen MJ, Sivan E, Chetrit A, Kuint J, Schiff E. Risk factors for neonatal thrombocytopenia in preterm infants. Am J Perinatol 2003;20:49-54.

28) Ohlin A, Bjorkman L, Serenius F, Schollin J, Kallen K. Sepsis as a risk factor for neonatal morbidity in extremely preterm infants. Acta Paediatr 2015;104:1070-6.

29) Guida JD, Kunig AM, Leef KH, McKenzie SE, Paul DA. Platelet count and sepsis in very low birth weight neonates: is there an organism-specific response? Pediatrics 2003;111:1411-5. 